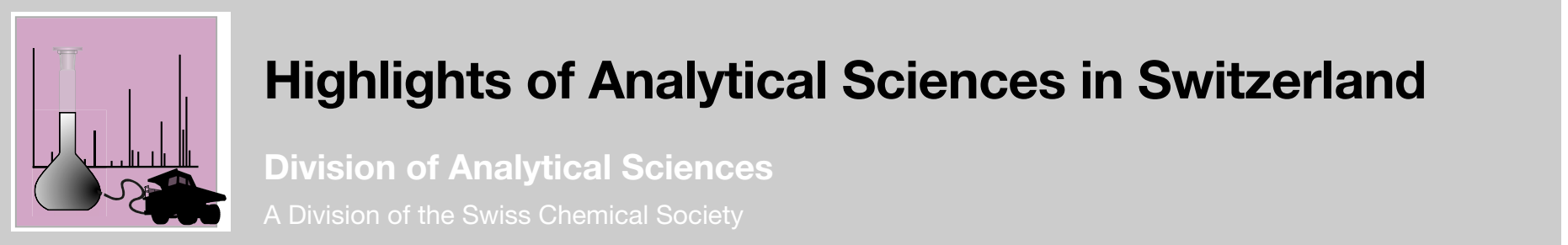

\section{Benefit-Risk Assessment of Diesel Particle Filters (DPFs): An Analytical and a Toxicological Challenge}

Norbert Heeb*a, Regula Haaga ${ }^{a}$, Peter Schmid ${ }^{a}$, Cornelia Seilera, Adrian Wichser ${ }^{\mathrm{a}}$, Markus Zennegg ${ }^{\mathrm{a}}$, Peter Honeggera ${ }^{a}$, Kerstin Zeyera, Lukas Emmeneggera, Yan Zimmerli ${ }^{\mathrm{b}}$, Jan Czerwinski ${ }^{\mathrm{b}}$, and Andreas Mayer ${ }^{\mathrm{c}}$

${ }^{*}$ Correspondence: Dr. N. Heeba , Tel.: +41 5876542 57,

E-Mail: norbert.heeb@empa.ch

aEMPA, Swiss Federal Laboratories for Materials Testing and Research, Ueberlandstrasse 129, CH-8600 Dübendorf. bUASB, University of Applied Sciences Biel, Gwerdtstrasse 5, CH-2560 Nidau. ${ }^{\circ}$ TTM, Technik Thermischer Maschinen, Fohrhölzlistrasse 14b, CH-5443 Niederrohrdorf

Keywords: Diesel particle filters · Genotoxicity · Heavy duty vehicles $\cdot$ Nitro-PAHs $\cdot$ PAHs $\cdot$ PCDD/Fs

Filter or no filter is not the question anymore, except perhaps in the Swiss parliament which voted against a retrofit program for heavy duty vehicles in May 2014. In R\&D, one asks if catalyzed or non-catalyzed filters are the best available technology for detoxification of diesel exhaust. Assessing the impact of filters on exhaust composition and toxicity is challenging for analytical chemists and toxicologists (see the Highlight of Bisig et al., Chimia 2015, 69, 68). Are toxic compounds reactive species triggering oxidative stress and inflammation, are they genotoxic inducing cancer or do they provoke other cell responses?

The endeavor 'NEAT' (Neue Alpentransversale, the new transalpine rail link) triggered various activities, among them the VERT project (Verminderung der Emissionen von Realmaschinen im Tunnelbau) - a joint effort from SUVA, BAFU, filter and catalyst manufacturers, TTM, and EMPA - to evaluate suitable filter technology for construction machinery to fulfill air quality standards in these long tunnels (Fig. 1).

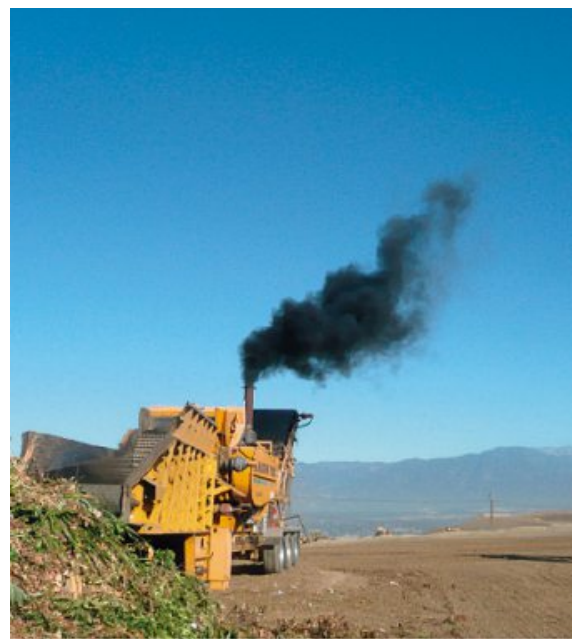

Fig. 1. Construction machinery in Switzerland has to be equipped with filters since 2009 , but most trucks on roads are not.

filters must convert genotoxic compounds such as polycyclic aromatic hydrocarbons (PAHs) but must not support a de novo formation of other pollutants such as nitro-PAHs and polychlorinated dibenzodioxins/furans (PCDD/Fs). Fig. 2 displays sampling filters, exposed to 7 $\mathrm{m}^{3}$ exhaust ( $3 \mathrm{~min}$ operation) of a heavy duty engine $(6.1 \mathrm{~L})$. A VERT-approved diesel particle filter was used in one case. The other sample represents untreated heavy duty vehicle exhaust (94\% of the Swiss HDV fleet).

Obviously, par-

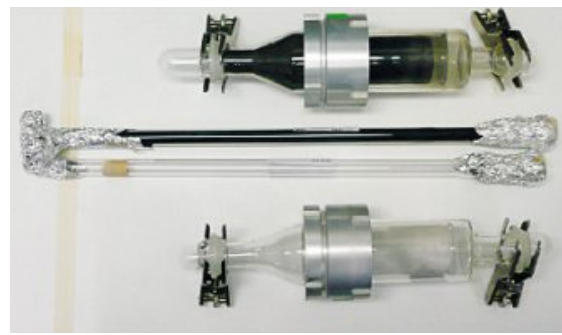

Fig. 2. Glass sampling devices exposed to $7 \mathrm{~m}^{3}$ exhausts of a heavy duty engine ( $3 \mathrm{~min}$ operation) with and without filter.

ticles are removed with filters, but semi-volatile compounds including genotoxic PAHs and nitro-PAHs are not necessarily converted. An assessment of filters, now described in the Swiss Norm 277206, also includes an evaluation of genotoxic compounds. EMPA has contributed congener-specific PAH, nitro-PAH and $\mathrm{PCDD} / \mathrm{F}$ analyses for $>40$ diesel particle filters with GC-HRMS.

Fig. 3 compares pyrene and 1-nitro pyrene penetration of

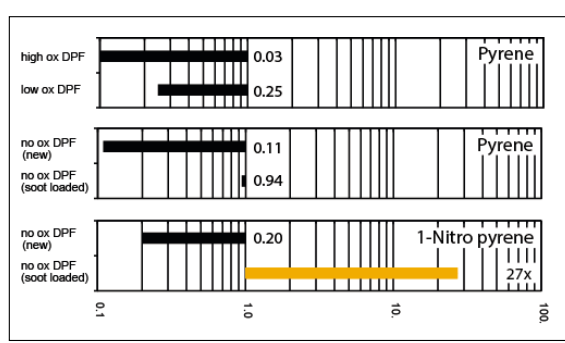

Fig. 3. Pyrene and 1-nitro pyrene penetration of filters with high, low and no oxidation potential (new and soot loaded) are compared. filters with high, low and no oxidation potential. Catalyzed filters convert pyrene $(75-97 \%)$. The non-catalyzed filter stored pyrene when new, but released it when soot-loaded. Such storage-release phenomena may occur when changing from cold to hot conditions (e.g. urban vs. highway driving). Emissions of 1-nitropyrene even increased for the non-catalyzed filter. A secondary formation of nitro-PAHs affects the exhaust genotoxicity. We conclude that filtration per se is not sufficient to lower genotoxicity. Genotoxic compounds must be combusted in filters with efficient catalysts.

Received: December 23, 2015

\section{References}

N. V. Heeb, P. Schmid, M. Kohler, E. Gujer, M. Zennegg, D. Wenger, A. Wichser, A. Ulrich, U. Gfeller, P. Honegger, K. Zeyer, L. Emmenegger, J. L. Petermann, J. Czerwinski, T. Mosimann, M. Kasper, A. Mayer, Environ. Sci. Technol. 2008, $42,3773$.

N. V. Heeb, P. Schmid, M. Kohler, E. Gujer, M. Zennegg, D. Wenger, A Wichser, A. Ulrich, U. R. S. Gfeller, P. Honegger, K. Zeyer, L. Emmenegger, J.

L. Petermann, J. Czerwinski, T. Mosimann, M. Kasper, A. Mayer, Environ. Sci. Technol. 2010, 44, 1078

N. V. Heeb, M. Zennegg, R. Haag, A. Wichser, P. Schmid, C. Seiler, A. Ulrich, P. Honegger, K. Zeyer, L. Emmenegger, P. Bonsack, Y. Zimmerli, J. Czerwinski, M Kasper, A. Mayer, Environ. Sci. Technol. 2013, 47, 6510. 